понятие «класс» само по себе является в данном случае проблемой. Как соотносится между собой при таком подходе психоидеология, например, городского мещанства и духовенства (в этой среде могли иметь хождение одни и те же литературные произведения)?

Кстати, ни в цитируемой, ни во многих других литературно-критических и публицистических работах Лелевич, собственно, и не демонстрирует одного из главных принципов диалектического материализма - единства и борьбы противоположностей. Реализация этого принципа более наглядно видна в статьях энциклопедии, редактируемой В. М. Фриче, где последовательно противопоставляются, а затем сводятся «теза» и «антитеза» художественного творчества ${ }^{17}$. Таким образом, отдельно еще стоит проблема последовательности эпигонства.

Следует отметить, что советское литературоведение не дало ответа на главный вопрос: диалектический материализм в модификации Плехановаэто конкретный и единичный метод, «порочная» альтернатива и искажение ленинского метода или методология как совокупность подходов?

Нет необходимости дополнительно аргументировать то, что деление на классы в разных странах и в разные исторические периоды не совпадает. Более того, определенные ограничения на модель, предложенную Плехановым, накладывает современная ситуация. Искусство XXI в., существующее в сфере интерактивной коммуникации, распространяемое с помощью огромного количества технических новшеств, явно внеклассово. Но дело не в оценке метода, ибо по природе не бывает стопроцентно объективной интерпретации художественного произведения, а в таксономии. Метод и мировоззрение - не одно и то же. Нет решительно никаких оснований для того, чтобы в современном гуманитарном обороте политическая позиция отождествлялась с методологической. Поэтому те приемы, которые Плеханов применяет к художественному тексту, подлежат пересмотру и реинвентаризации. Необходимо на новом этапе тщательно и убедительно обосновать,

УДК 821.111.09-2+929 Уайльд

\section{СВОЕОБРАЗИЕ КОНФЛИКТА} В ДРАМЕ ОСКАРА УАЙЛЬДА «САЛОМЕЯ»

\section{О. М. Валова}

Вятский государственный гуманитарный университет E-mail: olymihalna@yandex.ru

В статье предлагается анализ внешнего и внутреннего конфликта драмы 0. Уайльда «Саломея». Внешний конфликт связан с уайльдовской идеей губительности для человека его страстей, во внутреннем конфликте представлено воплоще- чем конкретный (взятый в иллюстративных примерах и цитатах) алгоритм анализа литературного творчества, проведенный Плехановым, коренным образом отличается от анализа культурно-исторической школы, сравнительного литературоведения. Все недостатки и достоинства Плеханова следует, несомненно, сформулировать заново, но уже исходя из того, что марксистская критика лишь мгновение в мировой литературной жизни, а не решающий ее этап, но и это мгновение достойно объективного изучения.

\section{Примечания}

1 См.: Елина Е. О соотношении понятий «литературный процесс» и «литературная жизнь» // Вопр. литературы. 1998. № 3.

${ }^{2}$ См.: Плеханов Г. Письма без адреса // Плеханов Г. В. Сочинения : в 24 т. М., 1932. Т. 14. С. 21.

3 Плеханов Г. Искусство и общественная жизнь // Там же. С. 126

4 Там же. С. 131.

5 Плеханов Г. Предисловие к третьему изданию «За двадцать лет» // Там же. С. 189.

6 Плеханов Г. Искусство и общественная жизнь. С. 163.

7 Бельчиков Н. Г. В. Плеханов - литературный критик. M., 1958. C. 6.

8 Розенталь М. Вопросы эстетики Плеханова. М., 1939. C. 16.

9 Там же. С. 131.

10 См.: Г. В. Плеханов - литературный критик. Новые материалы / ред. и предисл. И. Ипполита. М., 1933.

11 См.: Яковлев М. Плеханов как методолог литературы. Л. ; М., б. г.

12 Там же. С. 92.

13 Лелевич Г. Поэзия революционных разночинцев 60-80-х гг. ХІХ века. М. ; Л., 1931. С. 21.

14 Там же. С. 33.

15 Там же. С. 36.

16 Там же. С. 132-133.

17 См.: Благой Д. Блок А. А. // Литературная энциклопедия : в 11 т. М., 1929. Т. 1. С. 517-518.

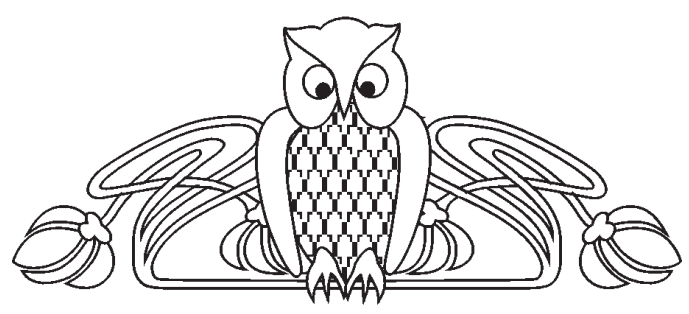

ние взглядов драматурга, связанных с его «философией нереального».

Ключевые слова: конфликт, «Портрет Дориана Грея», «Преступление лорда Артура Сэвила», «философия нереального». 


\section{Conflict Peculiarity in Oscar Wilde's Drama Salomé}

\section{O. M. Valova}

The article analyzes external and internal conflicts of Oscar Wilde's drama Salom. The external conflict reveals Wilde's idea of the destructive role of human infatuation. The internal conflict presents Wilde's views connected with his 'philosophy of the unreal'.

Key words: conflict, The Picture of Dorian Gray, Lord Arthur Savile's Crime, «philosophy of the unreal».

Конец XIX в. принято называть переходной эпохой, эпохой декаданса, это время значительных перемен во всех областях жизни человека: менялись социальный уклад, правовые основы существования государства, давал о себе знать сельскохозяйственный кризис, вызвавший приток ищущих заработок крестьян в город... Общая нестабильность, перемены, которое ведут к пугающему неизвестному, рождали ощущение покинутости, страха, неуверенности, которое отразились в литературе fin de siècle. В обществе возобновляется интерес к идеалистическим учениям, к тайнам бытия, мистическому, иррациональному, отмечается частое обращение к оккультным наукам, гаданию, различного рода предсказаниям.

По-своему отражает эти тенденции времени «новая драма» конца XIX в. Среди основных представителей данного направления в западноевропейской литературе российские исследователи называют Ибсена, Стриндберга, Золя, Гауптмана, Метерлинка, Шоу, Йейтса. В западном литературоведении в числе британских основоположников «новой драмы» критики отмечают имена Б. Шоу, Х. Гренвилл-Баркера, Д. Голсуорси. Имя Оскара Уайльда среди авторов этого направления упоминается факультативно, хотя и в его творчестве формировались особенности нового направления В драматическом искусстве. В 80-90-е гг. XIX в. театр становится одним из способов философского познания глубины, многомерности жизни, а в структуре пьес помимо внешнего конфликта появляется внутренний как отражение сложности и неоднозначности окружающего мира.

Трагедия «Саломея», над которой О. Уайльд работал вплоть до 1892 г., строится в традициях «новой драмы», в ней есть и актуальные проблемы нравственности, и столкновение идей, и острый морально-философский конфликт. Предметом исследования в данной статье является внешний и внутренний конфликт уайльдовского текста, который выражает идейно-философские установки автора.

В основе трагедии «Саломея» лежит библейская история о смерти Иоанна Крестителя, изложенная в Евангелии (Мф. 14:8-11, Мк. 6:14-28, Лк. 3:19-20). Известный сюжет неоднократно интерпретировался в искусстве конца XIX в. Так, Стефан Малларме пишет драму «Иродиада» (1867), в 1877 г. вышла «Иродиада» Гюстава Фло- бера, к этому сюжету обращался и Жюль Лафорг в «Моральных легендах» (1887). На ту же тему написана опера Ж. Массне «Иродиада» (первая постановка 1881 г.). Образ Саломеи был воплощен на живописных полотнах Г. Моро, а в 1884 г. в романе «Наоборот» Ж.-Ш. Гюисманс опишет эти картины. Рисовал Саломею и Обри Бердслей - именно его рисунки настолько понравились Уайльду, что он попросил молодого художника оформить его новую книгу. Проповедующий Иоанн Креститель представлен и в скульптуре О. Родена (1879).

По воспоминаниям современников, Уайльд обращался к библейскому сюжету о смерти Иоанна Крестителя неоднократно, об одном из первых упоминаний говорит Р. Эллман. Это произошло в студенческие годы Уайльда, после зачисления в масонскую ложу Аполлона. Соученик Уайльда по Оксфорду Дж. Бодли писал в своем дневнике об ужине, который состоялся 23 февраля 1875 г. после заседания масонской ложи. «Уайльд очень развеселился, - пишет Бодли, - и по моей просьбе завербовал в ложу Иоанна Крестителя. "Я слыхал, - сказал он, - что основателем нашего Братства был Иоанн Креститель [взрыв смеха]. Я надеюсь, мы будем подражать только его жизни, но не его смерти - ведь нам не с руки терять голову"» ${ }^{1}$. На этот сюжет Уайльд впоследствии планировал написать рассказ, позже - стихотворение, но с течением времени замысел оформился в пьесу.

В заглавие драмы Уайльд вынес имя иудейской царевны Саломеи. В Евангелии оно не упоминается, но в произведении Саломея становится одной из главных героинь. Очарованная сначала голосом пророка, Саломея воспылала страстью, как только впервые увидела его. С этого момента героиню больше не волнует ничего, что происходит вокруг: она «не слышит» содержания речей Иоканаана, «не слышит» о смерти молодого сирийца, влюбленного в нее, «не слышит» мать, когда та просит не танцевать для Ирода, - Саломея полностью поглощена своей страстью.

Русские критики начала XX в. писали о Саломее в основном с сочувствием. Н. Я. Абрамович еще в работе 1909 г. указал на «невиновность» героини, которая была «орудием» жизни. Исследователь считал, что жизнь утверждала Саломеей «единый закон своей гармонии, разорванной бешеной страстностью экстатика-пророка» ${ }^{2}$. П. Коган полагал, что в Саломее «воплотил поэт свою мечту о преображении мира через любовь» ${ }^{3}$. К. Бальмонт, переводивший «Саломею», считал героиню женщиной с красивой, как рассвет, душой. «Я вижу Саломею, - писал он, - незапятнанной в веках, увенчанной всем ее девическим блеском...» ${ }^{4}$.

Новая волна интереса к «Саломее» появляется во второй половине XX в., и теперь критики иначе оценивают героиню трагедии, ее образ видится неоднозначно. Так, Н. В. Тишунина подмечает двойственность образа Саломеи в том, что, с одной стороны, она несет смерть, а с другой - это юная, 
невинная, влюбленная девушка, которая является орудием «неукротимой силы любви» ${ }^{5}$. А. Г. Образцова указывает на такие черты Саломеи, как чувственность, властность, одиночество ${ }^{6}$, К. Н. Савельев подчеркивает ее хищнический инстинкт, страстность, которая не может быть утолена 7 .

Зарубежные исследователи более склонны видеть в Саломее порочное начало. Так, американский критик К. Палья называет Саломею «позднеромантическим вампиром, замораживающим Иоанна своим агрессивным взглядом Медузы, и вводящей его в конечную пассивность смерти» ${ }^{8}$. К. Нассаар считает, что Саломея представляет образец души полностью злой 9 . М. Нокс, которая рассматривает творчество Уайльда под углом его гомосексуальных наклонностей и детских сексуальных впечатлений, говорит, что все основные символы «Саломеи» уходят корнями в детство писателя. Например, Саломея ассоциируется с умершей сестрой Уайльда Изолой, о чем свидетельствует одно из первых упоминаний о луне, которая напоминает женщину, вставшую из могилы. Кроме того, по мнению Нокс, драматург сравнивает Саломею с Бози и их обоих с Изолой ${ }^{10}$.

По воспоминаниям современников, Уайльд относился к своей героине неоднозначно и во множестве вариантов своей интерпретации библейского сюжета о смерти Иоанна Крестителя представлял Саломею то воплощением чистоты, то вместилищем порока. Когда шла подготовка к постановке пьесы, разработкой декораций и костюмов занимался Ч. Риккетс. Уайльд предложил сделать костюм Саломеи «зеленым, как диковинная ядовитая ящерица» ${ }^{11}$. Возможно, образ Саломеи в какой-то мере слился в воображении Уайльда с восприятием образа Сары Бернар, которую он называл «змеей древнего Нила» $^{12}$ (планировалось, что именно она будет исполнительницей роли принцессы). Но вспомним и описание миссис Чивли из «Идеального мужа». В третьем действии она приходит к лорду Горингу, чтобы предложить взамен украденного письма свою руку («Так вот, - говорит она, - утром того дня, когда мы с вами поженимся, я вам отдам письмо Роберта Чилтерна» ${ }^{13}$ ). В этом действии миссис Чивли одета в зеленое с серебром и как никогда похожа на змею. Очевидно, что Уайльд представляет тип героинь, которые ассоциируются у него со змееподобными существами, опасными, дерзкими, готовыми ради удовлетворения своей страсти или заполучения выгоды безжалостно впрыснуть яд жертве. Действительно, «невинность» - не то качество, которым автор наделяет свою героиню. Жак де Ланглад приводит еще одно описание костюма Сары Бернар: она должна быть совершенно обнаженной, украшенной лишь многочисленными драгоценностями. «Дело в том, - говорил Уайльд, - что я не могу представить себе Саломею, творящую свои деяния неосознанно, Саломею, которая была бы всего лишь пассивным инструментом...» ${ }^{14}$.
С образом Саломеи связан внешний конфликт: обычно в произведениях Уайльда заглавие указывает на основных героев или ведущие проблемы внешнего действия. Завязкой можно считать смерть Молодого сирийца. Он убивает себя, когда видит, что все внимание его возлюбленной поглощено Иоканааном. Тело юноши падает между пророком и Саломеей, таким образом Уайльд показывает, что герои изначально разделены смертью. Эта сцена является начальной для развития действия, поскольку здесь переплетаются традиционные для Уайльда тема взаимосвязи любви и смерти, тема выбора (Саломею не остановила смерть Молодого сирийца), тема неукротимых желаний. Героиня стремится к поцелую, несмотря на смерть, несмотря на неприятие самого Иоканаана.

Далее Уайльд наблюдает за развитием чувства Саломеи, которое становится всепоглощающей страстью. Осознавая невозможность ее утоления, героиня лишает жизни Иоканаана и целует отрубленную голову пророка. В момент поцелуя действие достигает наивысшего напряжения, это кульминационный эпизод драмы, так как здесь проявляется мощь чувства, охватившего Саломею. О. Ковалева, исследовавшая вопрос о своеобразии воплощения основных черт модерна в творчестве Уайльда, указывает на поцелуй как на одну из знаковых черт: «Модерн, любящий выявить экстатический порыв, <..> подобно К. Бальмонту пропел "псалом" поцелую: О. Роден "Поцелуй" (1886), П. Беренс "Поцелуй” (1898), Г. Климт “Поцелуй” (1907-1908), К. Сомов “Осмеянный поцелуй” (1908). Поцелуй - устойчивый мотив и в мире Уайльда - всегда осуществляется на грани жизни и смерти» ${ }^{15}$. Развязкой драмы становится смерть самой Саломеи как закономерный итог ее поступка.

Во внешнем действии Уайльд реализует свою идею о губительности для человека его пороков и порочных слабостей. Эта же мысль станет более очевидной в комедии «Идеальный муж» (1895). Миссис Чивли приезжает в дом Роберта Чилтерна, чтобы с помощью шантажа заставить его поддержать идею строительства Аргентинского канала проект, в который вложены ее капиталы. Кажется, что шантажистка продумала все до мелочей и у Чилтерна нет выхода, но ее план провалился изза собственного пристрастия к воровству. Когда на руке миссис Чивли защелкнулся украденный браслет, ей пришлось распрощаться со своими прежними замыслами. То есть к провалу миссис Чивли привели ее порочные страсти, что мы видим и в написанной ранее «Саломее».

Все же более значимые для Уайльда вопросы обсуждаются им в ходе внутреннего действия драмы, которое связано с образом Иоканаана. Иоканаан - греческий вариант имени Иоанн, и речь здесь идет об Иоанне Крестителе (Иоанне Предтече) - пророке, который должен предвозвестить приход мессии. 
Критики довольно часто обвиняют Иоканаана в бесчувственности, отсутствии гуманности, фанатизме. Например, К. Бальмонт говорит, что «дьявольскую» атмосферу пьесы обусловил поступок Иоканаана, оттолкнувшего Саломею ${ }^{16}$. Н. Минский считает, что своей безжалостностью Иоканаан духовно убил Саломею, которой «не оставалось ничего другого, как любить бездушное, как утолить свою жажду поцелуя над мертвыми устами» ${ }^{17}$. Аналогичное мнение высказывает Н. Дроздова, которая пишет, что молодость и красота Саломеи не только не волнуют пророка, но и неприятны ему, почему Иоканаан и прогоняет Саломею $^{18}$. По мнению Н. Тишуниной, Иоканаан «представляет фанатично-экстатическое сознание, замкнутое на себе, абсолютно невосприимчивое ни к каким другим голосам» ${ }^{19}$. А. Г. Образцова называет Иоканаана «пророком-фанатиком», который «не умеет прощать человеческие грехи» ${ }^{20}$.

Мнение зарубежных исследователей об Иоканаане сходно. Так, К. Уорт пишет, что в «Саломее», как и в комедии «Как важно быть серьезным», много абсурдного. Среди абсурдных сцен в драме она называет ту, где мужчина, давший обет безбрачия (Иоканаан), гневно обличает женщин ${ }^{21}$. $\mathrm{X}$. Маркович обвиняет героя в том, что он не замечает в Саломее самостоятельной духовной личности ${ }^{22}$. В целом литературоведы видят в Иоканаане фанатика, забывая о мистической составляющей этого образа. Для более глубокого его понимания следует обратиться к другим произведениям Уайльда.

Критики часто указывали на сходство событийных поворотов, свойств характеров или взглядов героев Уайльда. Кажется, что писатель «проигрывает» сюжет в различных обстоятельствах или находит новые художественные доказательства для своих эстетических взглядов. «Саломея» по разным параметрам сопоставляется с его комедиями и романом «Портрет Дориана Грея» (К. Нассаар, К. Уорт, Х. Маркович). В этом ряду вспомним и одно из ранних произведений Уайльда - рассказ «Преступление лорда Артура Сэвила» (1887). На наш взгляд, образ Иоканаана в «Саломее» имеет довольно много общего с образами хироманта Поджерса («Преступление лорда Артура Сэвила») и художника Бэзила Холлуорда («Портрет Дориана Грея»), их сопоставление позволяет найти в текстах новые смысловые уровни, увидеть воплощение эстетических взглядов Уайльда в драме «Саломея».

В «Преступлении...» речь идет о предсказании Поджерса молодому очаровательному лорду Артуру Сэвилу. Интерес Уайльда к хиромантии не был вызван лишь настроениями эпохи, он был знаком с известными хиромантами своего времени Э. Герон-Алленом и Л. Хамоном (Каейро). Эдвард Герон-Аллен (1861-1943), ученый и практик, популяризировал хиромантию как современную науку. Он был разносторонним человеком, его увлечения простирались от метеорологии до геральдики, он внес значительный вклад в хиромантию, писал книги, проводил спиритические сеансы, читал лекции. Первая книга Герон-Аллена по хиромантии была опубликована в 1883 г., вторая - двумя годами позже. Герон-Аллен составил гороскоп сыну Уайльда Сайрилу, а также схему руки самого Уайльда и хранил ее наряду с изображениями рук других известных людей ${ }^{23}$.

Предсказания по руке писателя делал и Л. Хамон (Каейро). Р. Эллман описал случай, который произошел с Уайльдом: «Кайеро нашел линии на двух его ладонях настолько различными, что счел нужным объяснить: в хиромантии левая рука показывает наследственные тенденции, правая индивидуальные особенности. У человека, чьи руки он видит, левая обещает блестящий успех, правая - надвигающуюся катастрофу. <..> Не проронив больше ни слова, Уайльд покинул званый обед» ${ }^{24}$. Исследователи отмечают суеверность Уайльда, ощущение рока, которое не покидало писателя на протяжении всей жизни, его внимание к теме судьбы, которая начинает развитие в рассказе о лорде Артуре и хироманте Поджерсе, а продолжается в романе, пьесах, эссе, тюремной исповеди.

Очевидно сходство в описании встречи хироманта Поджерса («Преступление лорда Артура Сэвила») и Бэзила Холлуорда («Портрет Дориана Грея») с героями, от руки которых им предстоит погибнуть: «Но, взглянув на руку лорда Артура, мистер Поджерс странно побледнел и не произнес ни слова». Лорд Артур почувствовал, что ему хочется «повернуться и бежать, но он сдержал себя» (I, 216). Лорд Артур попытался «вытянуть» из хироманта информацию, а после ужина они вновь случайно повстречались: «Внезапно в гостиную вошел мистер Поджерс. Увидев лорда Артура, он вздрогнул, и его крупное, одутловатое лицо стало зеленовато-желтым. Их глаза встретились, и с минуту оба молчали» (I, 218). Герой настоял, чтобы хиромант рассказал обо всем, что смог прочитать по его руке. Растерянный и сбитый с толку Поджерс поведал, что лорд Артур должен совершить убийство.

Сравним историю хироманта с описанием первой встречи Бэзила Холлуорда и Дориана Грея. Беседуя с гостями леди Брэндон, он почувствовал на себе чей-то взгляд. «Я оглянулся и тут-то в первый раз увидел Дориана Грея. Глаза наши встретились, и я почувствовал, что бледнею. Меня охватил какой-то инстинктивный страх, и я понял: передо мной человек настолько обаятельный, что, если я поддамся его обаянию, он поглотит меня всего, мою душу и даже мое искусство. <..> Мне стало жутко, и я уже шагнул было к двери, решив уйти. Сделал я это почти бессознательно, из какой-то трусости. <..> И вдруг я очутился лицом к лицу с тем самым юношей $<\ldots>$ Тут я безрассудно попросил леди Брэндон познакомить нас. Впрочем, это, пожалуй, было не такое уж безрассудство: все равно, если бы нас и не по- 
знакомили, мы неизбежно заговорили бы друг с другом. Я в этом уверен. Это же самое сказал мне потом Дориан. И он тоже сразу почувствовал, что нас свел не случай, а судьба» (I, 26-27).

И Поджерс, и Холлуорд не могут предотвратить встречи, которая станет для них роковой. Оба героя бледнеют, меняются в лице, ими овладевает безотчетный страх и они стремятся избежать более близкого знакомства. Но по стечению обстоятельств происходит повторное столкновение героев, из чего мы можем судить, что, во-первых, человеку не дано изменить предначертанного и, во-вторых, судьбу вершат случай или решения, не контролируемые рассудком.

В «Саломее» сложность отношений главных героев изначально определяется тем, что Иоканаан - пророк, он глубже, чем все остальные, осмысливает действительность, обладает особым даром, поэтому, увидев принцессу, Иоканаан узнал ту, которая станет причиной его гибели. Далеко не все исследователи обращают внимание на этот факт, гораздо более распространенным является мнение, что пророк, как пишет Х. Маркович, разговаривая с Саломеей, видит в ней только то, что она - дочь Иродиады ${ }^{25}$. Стоит ли обвинять Иоканаана в неприязненном отношении к принцессе, когда он говорит: «Что это за женщина смотрит на меня? Я не хочу, чтобы она смотрела на меня. Что она смотрит на меня своими золотыми глазами под золотыми веками? Я не знаю, кто она. Не хочу знать, кто она. Пусть она уйдет. Не с ней хочу я говорить» ${ }^{26}$.

Данный эпизод можно рассматривать как завязку внутреннего конфликта, который обусловлен темой судьбы. Образ Иоканаана, олицетворяющего явление иррационального в земном мире, иллюстрирует положение Уайльда о закономерностях поглощения искусства жизнью. В трактате «Упадок лжи» автор выделяет три этапа этого процесса. Сначала художник обращается к нереальному, несуществующему и с помощью воображения создает нечто восхитительное. Далее жизнь «просит, чтобы ей разрешили вступить в этот магический круг», в третьей же стадии «Жизнь все-таки одерживает победу, изгоняя Искусство в места необитаемые» (II, 228). Особенно ярко эта идея раскрывается в романе «Портрет Дориана Грея», но в «Саломее», над которой автор работал практически параллельно с романом, мы видим проявление аналогичных процессов, «Жизнь» здесь олицетворяет иудейская принцесса.

Кульминацией внутреннего конфликта становится танец Саломеи, которым она «выкупает» голову Иоканаана. Данный эпизод рассматривается исследователями как ключевой, в нем концентрируется несколько линий авторского повествования ${ }^{27}$. Еще в сказках мотиву танцев Уайльдом отводилась знаковая роль. Е. Куприянова, исследовавшая этот вопрос, отмечает, что с танцем связан мотив телесной греховности, а в «Саломее», по ее мнению, «танец используется как символ плот- ского обольщения и искушения» ${ }^{28}$. Танец имеет обрядовую природу, и О. Фрейденберг пишет, что «'танец', 'пляска' сперва связываются со светом, с новым сиянием солнца, с его новым рождением, а затем с половым актом и срамными действами, хотя одновременно и в музыке, и в пляске, и в слове интерпретируется реальная действительность с ее производственно-трудовыми процессами» ${ }^{29}$. «Энциклопедия символов» указывает, что танец «выступает как средство приведения собравшихся в экстатическое состояние» ${ }^{30}$. В. Решетов полагает, что в рассматриваемой сцене автор также воплощает свои эстетические взгляды: «Сопоставляя различные виды искусств, Уайльд в эссе “Критик как художник” вслед за Лессингом отметил, что “движение, эта главная проблема для зрительных искусств, в сущности, может быть передано одной Литературой. Она одна показывает нам тело в его стремительности и душу в ее беспокойстве". В “Саломее” он наглядно продемонстрировал страстное движение героини в танце как необходимый элемент соблазнения Ирода и страстное желание любви Иоканаана в ее душе, достигнув консенсуса между различными видами искусства» ${ }^{31}$.

На рубеже XIX-XX вв. отмечается стремление различных художественных форм проникнуть в жизнь, сломив исключительную духовность культуры. «Первые пробы, - пишет Г. Фукс, были произведены в поэзии, литературе, архитектуре, в орнаментальном искусстве, в устройстве квартир, наконец, в одежде. Но позже всего нашли ближайшее: собственное тело» ${ }^{32}$. Не вызывает сомнения, что и танец Саломеи становится проявлением греховности, порочности человеческой природы, которой противостоит духовная чистота Иоканаана.

В произведениях Уайльда просматривается оппозиция движение / статика, с которой связаны характеристики персонажей: автор всегда был на стороне героев, которые предпочитают созерцательность активности. Танец относится к физическим действиям, то есть к категории «поступков», которые практически всегда осуждаются писателем. «Одни тупицы да доктринеры, люди ужасающе скучные, тщатся подкрепить свои принципы бессмысленными поступками, обожая практику...» (II, 219), - писал он в трактате «Упадок лжи». В «Душе человека при социализме» он дополнял: «Человека не всегда характеризуют его поступки. Он может чтить законы, но быть дрянным. Он может преступить закон, но оставаться прекрасным человеком» (II, 353). Можно посмотреть на танец и с другой стороны, ведь с его помощью Саломея «покупает» тело Иоканаана, а к торговле (в любых ее проявлениях) Уайльд относился как к проявлению низменных свойств человеческой природы ${ }^{33}$. Таким образом, как бы ни был красив и притягателен танец Саломеи, он дополняет ее отрицательную характеристику. 
Танец Саломеи является кульминационным эпизодом в развитии внутреннего действия, поскольку его обольстительная сила лишает Ирода самостоятельности в принятии решения, а в итоге побеждает и духовную мощь пророка. Смерть Иоканаана, таким образом, становится развязкой конфликта.

«Интерпретируя в “Саломее” библейскую легенду, предавая смерти обоих - Саломею и Иоканаана, - Уайльд превращает добродетель в разновидность греха, отказывает излишествам духа в каких-либо преимуществах перед иными формами излишеств», - писал Р. Эллман, объясняя финал драмы ${ }^{34}$. К. Нассаар также уверен, что в «Саломее» есть своя мораль. В «Портрете Дориана Грея» она заключалась в том, что всякая неумеренность должна быть наказана. В драме Уайльд подводит к мысли о необходимости пропорционального соотношения добра и зла в человеке, поскольку, например, подавление Иоканааном своей злой природы ведет его к духовной, а затем к физической смерти, и то же самое происходит с Саломеей, неспособной сдержать свою страсть ${ }^{35}$. Т. Боборыкина считает, что «Саломея» - трагедия взаимного непонимания ${ }^{36}$. Н. Тишунина главной идеей пьесы называет «мысль о непостижимости, неразгаданности человеческой души» ${ }^{37}$. А. Тетельман полагает, что конфликтом пьесы становится «противоборство “непреклонных воль”». Каждый из героев пьесы охвачен определенной страстью, которая разрушает личность и ведет к гибели. «Для Саломеи - это желание поцеловать Крестителя, для Иоканаана - это стремление познать тайну Бога» ${ }^{38}$.

На наш взгляд, «Саломея» Уайльда не только запечатлела в себе дух времени, но и стала одним из самых ярких проявлений «философии нереального» драматурга.

Термин «философия нереального» («Philosophie de l'Irréalité») появляется в письме Эдмону де Гонкуру от 17 декабря 1891 г., где Уайльд отмечет, что философия нереального является интеллектуальной основой его эстетики ${ }^{39}$. Писатель не расшифровывает суть понятия, но анализ художественных текстов, статей, писем, эстетических миниатюр позволяет говорить о пристальном внимании Уайльда к проблемам власти иррационального, вопросам осмысления роли и места человека в мире, где логика и рассудок бессильны. Изучение уайльдовского наследия с позиций его «философии нереального» весьма продуктивно, поскольку позволяет раскрыть новые грани таланта писателя.

Смерть становится участью Саломеи и Иоканаана, но причины их гибели с точки зрения уайльдовской «философии нереального» идейно значимы. Судьба Саломеи связана с жизнью в мире людей, и причиной ее смерти становится незаурядная, сильная страсть.

Судьба Иоканаана свидетельствует о размышлениях драматурга более общего порядка, в ней Уайльд воплощает один из ключевых тезисов трактата «Упадок лжи» о поглощении искусства обыденностью. Подлинным декадансом и трагедией современности Уайльд считает победу Жизни над Искусством ${ }^{40}$.

Продолжая сопоставление «Саломеи» с более ранними произведениями Уайльда, обратимся к сказке «Счастливый принц», вошедшей в одноименный сборник (1888). Ее финал показывает, что, по мнению писателя, высший суд вершит не человек, а иррациональное.

В центре сказки - история о любви Ласточки к Принцу и добрых делах, которые героиня совершала во имя любви. Это повествование обрамляют диалоги горожан и чиновников, которые своим вполне справедливым решением стремятся облагородить город и приказывают убрать тело мертвой Ласточки и статую Счастливого Принца, потерявшую свой привлекательный вид. Эти события, с одной стороны, прочитываются как победа обывателей над духовностью и красотой, но с другой стороны, финал сказки, в котором Господь просит ангела принести две самые ценные вещи в городе (тело мертвой Ласточки и разорвавшееся сердце Счастливого Принца), говорит о том, что человек слишком мал, чтобы быть судьей над миром, где властвуют другие, более мощные силы.

В «Саломее» смерть героини становится неизбежной, формально она обусловлена приказом Ирода, но Уайльд рисует эту сцену так, что сомнений в сверхличностном решении вопроса о судьбе иудейской принцессы нет. Главным доказательством этого положения становится ремарка: «Луч луны падает на Саломею и освещает ее». В образной системе Уайльда луна связана с иррациональным и подчеркивает мистическую власть потусторонних сил над человеком.

Ирод (оборачивается и видит Саломею). Убейте эту женщину.

(Солдаты бросаются и шитами своими раздавливают Саломею, дочь Иродиадь, ичаревну Иудейскую) (294).

Начиная с самых ранних работ очевидно внимание Уайльда к образу луны, который всегда связывается у него с загадкой, непознаваемым, непостижимым. Драматург не принимал «сиюминутных» тем, поэтому его обращение к таинственным образам вполне закономерно. Фантастический лунный мир, который присутствует в произведении, придает ему глубину, подчеркивая наличие иной реальности, внутренней связи человека со стихиями, мистической составляющей мира.

В драматических произведениях Уайльда всегда присутствует внешний и внутренний конфликт. Внешний связан с актуальной проблематикой (например, политическая нечистоплотность в «Идеальном муже», переоценка вопроса о порядочной / непорядочной женщине в «Веере леди Уиндермир», проблема брака в «Женщине, не стоящей внимания», проблема терроризма в «Вере, 
или нигилистах» и т. д.) и новыми тенденциями в современном искусстве. Уайльдовская Саломея виделась в ряду «роковых женщин», какими было заполнено искусство конца XIX в. Н. Тишунина пишет, что образ la femme fatale намечается уже в поэзии А. Суинберна: «Это образ женщины одновременно чувственной и надменной, таинственнообольстительной и порочной, притягательной и отталкивающей, несущей в себе трагедию внутреннего одиночества и вечно окруженной ее жертвамипоклонниками» ${ }^{41}$. Саломея с ее всепоглощающей страстью, несущей смерть, вполне вписывалась в этот контекст и воспринималась как образ, характерный для искусства той поры. Но, на наш взгляд, более полного изучения требует содержательная многослойность драмы, обусловленная комплексом философско-эстетических взглядов Уайльда и его «философией нереального», которые воплотились во внутреннем конфликте трагедии.

\section{Примечания}

1 Цит. по: Эллман Р. Оскар Уайльд : биография. М., 2000. C. 60 .

2 Абрамович Н. Религия красоты и страдания. Оскар Уайльд и Достоевский. СПб., 1909. С. 80.

3 Коган П. Очерки по истории западно-европейских литератур. М., 1911. С. 289.

4 Бальмонт К. Об Уайльде в России // Уайльд О. Саломея / пер. К. Бальмонта. СПб., 1908. С. 10.

5 Тишунина Н. Западноевропейский символизм и проблема взаимодействия искусств : опыт интермедиального анализа. СПб., 1998. С. 149.

6 См.: Образцова А. Волшебник или шут? (Театр Оскара Уайльда). СПб., 2001.

7 См.: Савельев К. Литература английского декаданса : истоки, генезис, становление : монография. Магнитогорск, 2007. С. 207-227.

8 Палья К. Личины сексуальности : пер. с англ. Екатеринбург, 2006. С. 712.

9 См.: Nassaar C. Into the Demon Universe : A Literary Exploration of Oscar Wilde. New Haven ; L., 1974. P. 93.

${ }^{10}$ См.: Knox M. Oscar Wilde : A long and lovely suicide. New Haven ; L., 1994. P. 27-34.

11 Эллман Р. Указ. соч. С. 424.

12 Там же. С. 423.

13 Уайльд О. Избранные произведения : в 2 т. : пер. с англ. М., 1993. Т. 1. С. 493. Далее ссылки на это издание даются с указанием тома и страницы.

14 Цит. по: Ланглад Ж. де. Оскар Уайльд, или Правда масок. М., 1999. С. 182.

15 Ковалева О. Оскар Уайльд и стиль модерн. М., 2002. C. 28.

16 См.: Иванова А. К. Д. Бальмонт - переводчик английской литературы. Иваново ; СПб., 2009. С. 246.

17 Минский Н. Идея «Саломеи» // Золотое руно. 1908. № 6. C. 58.

18 См.: Дроздова Н. Преломление христианских мотивов в духе традиций эстетизма (по страницам трагедии
Оскара Уайльда «Саломея») // Изв. Пензенск. ун-та. 2010. № 15(9). С. 21.

19 Тишунина Н. Указ. соч. С. 150.

20 Образцова А. Указ. соч. С. 158.

21 См.: Worth K. J. The Irish drama of Europe from Yeats to Beckett. L., 1978. P. 105.

22 См.: Marcovitch H. The Princess, Persona, and Subjective Desire : A Reading of Oscar Wilde's Salome // Papers on Language \& Literature. Winter 2004, Vol. 40. Issue 1. P. 95.

23 См.: Navarre J. Oscar Wilde, Edward Heron-Allen and the Palmistry Craze of the 1880s // English Literature in Transition, 1880-1920. 2011. Vol. 54. Issue 2. P. 174-184.

24 Эллман Р. Указ. соч. С. 434.

25 См.: Marcovitch H. Op. cit. P. 99.

26 Уайльд О. Пьесы. М., 1960. С. 272. Далее сноски на это издание даются в тексте с указанием страницы.

27 См.: Quigley A. E. Realism and Symbolism in Oscar Wilde's Salomé // Modern Drama. Toronto, 1994. Vol. 37. Spring № 1. P. 114-115.

28 Куприянова Е. Литературные сказки Оскара Уайльда и сказочно-мифологическая поэтика романа «Портрет Дориана Грея». Великий Новгород, 2007. С. 205.

29 Фрейденберг О. Поэтика сюжета и жанра. М., 1997. C. 123.

30 Бауэр В., Дюмоти И., Головин С. Энциклопедия символов / пер. с нем. Г. Гаева. М., 1998. С. 240.

31 Решетов В. Пьеса О. Уайльда «Саломея» в контексте трактовки библейских образов в других видах искусства // Взаимодействие литературы с другими видами искусства : XXI Пуришевские чтения : сб. ст. и материалов междунар. конф., 8-10 апреля 2009 г. / Моск. пед. гос. ун-т ; отв. ред. Е. Н. Черноземова ; ред кол. : Н. П. Михальская [и др]. М., 2009. С. 221.

32 Фукс Г. Танец // Фиал страстей. СПб., 1910. С. 61.

33 В произведениях Уайльда куплей-продажей, как правило, занимаются те, в ком преобладает рассудок. Например, в «Портрете Дориана Грея» состоятельность американцев обеспечена в основном торговлей (свининой, мануфактурой), в комедии «Веер леди Уиндермир» отец мистера Хоппера «нажил огромное состояние продажей каких-то консервов» (I, 350). К таким персонажам Уайльд относится без симпатии.

34 Эллман Р. Указ. соч. С. 411.

35 См.: Nassaar C. Op. cit. P. 103.

36 См.: Боборыкина T. Трагедии О. Уайльда (К проблеме связи творчества О. Уайльда с романтической традицией) // Проблемы жанра литератур стран западной Европы и США (XIX - первая половина XX вв.) : межвуз. сб. научн. тр. Л., 1983. С. 15.

37 Тишунина Н. Указ. соч. С. 105.

38 Тетельман А. Взаимодействие жанров в творчестве Оскара Уайльда : дис. ... канд. филол. наук. Казань, 2007. С. 74.

39 См.: Уайльд О. Письма. М., 1997. С. 106.

40 Collected Works of Oscar Wilde. The Plays, the Poems, the Stories and the Essays including De profundis. L., 1997.

41 Тишунина Н. Указ. соч. С. 138. 